\title{
The Use of Facial Characteristics AS ENGENDERING STRATEgIES IN Phoenician-Punic Studies
}

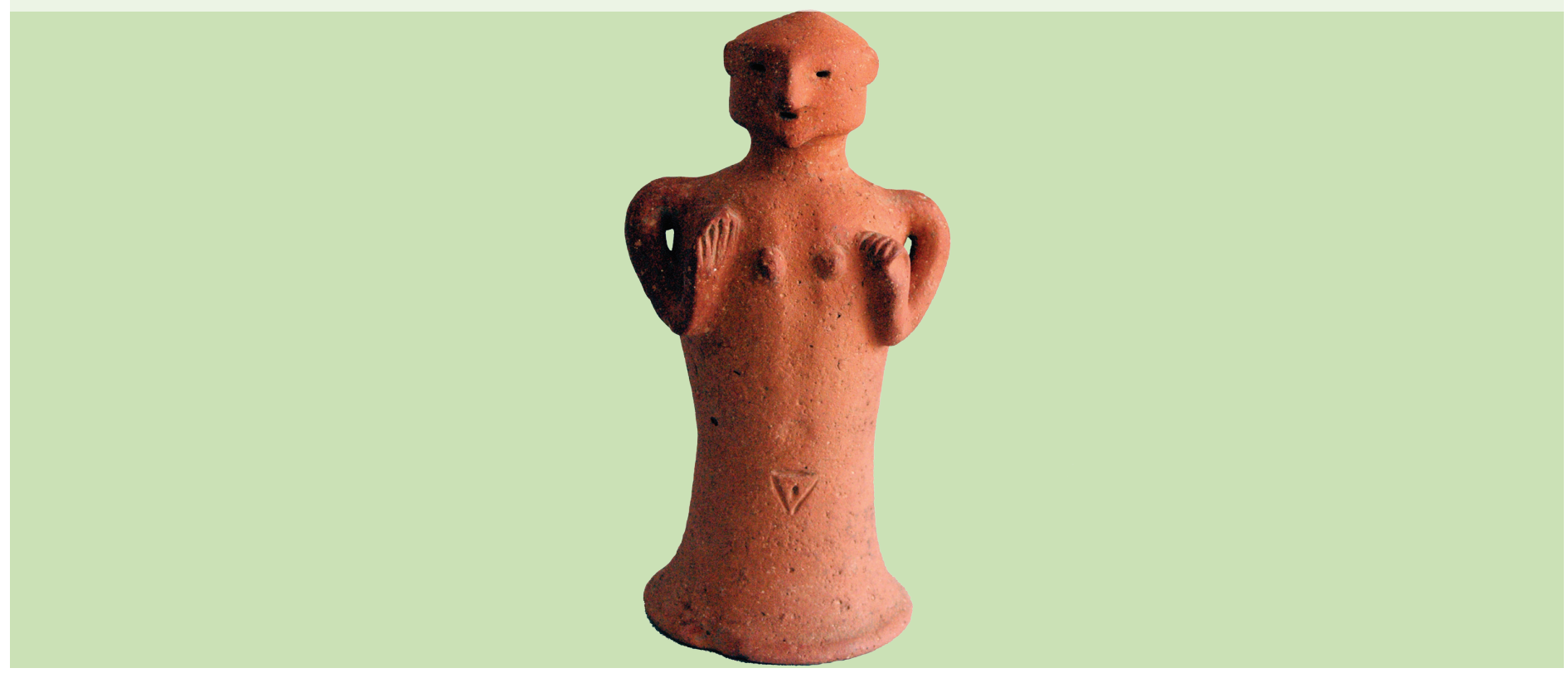

Clay figure from the Illa Plana shrine (Ibiza). Photograph courtesy of the Museu Arqueològic d'Eivissa i Formentera.

\section{Mireia López-Bertran and Agnès Garcia-Ventura}

I this paper, we consider four categories of Phoenician-Punic artifacts and how they have been engendered in modern scholarship, specifically with regard to facial characteristics: mold-made musician figurines, bottle-shaped figurines, and masks both of terracotta and painted ostrich eggshell. ${ }^{1}$ Although we shall not discuss these objects in depth, we contend that it is worthwhile to consider them together in order to draw attention to the strategies used to engender these objects in Phoenician-Punic studies, as they present some common facial characteristics which have been interpreted quite differently by scholars in terms of their relationship to gender.

Regarding the context and chronology of our study: the Phoenician trade diaspora from the Eastern Mediterranean to the Atlantic was a movement of people driven mainly by economic needs roughly dated to between the mid-ninth and seventh centuries B.C.E (fig. 1) (see Aubet 2001 for an overview). The subsequent Punic period is dated between the sixth and second centuries B.C.E. The term "Punic" implies a chronological distinction between the earlier Phoenicians-people from the Levant and the earliest settlers in the Mediterranean-and their descendants who populated the Western Mediterranean and the Atlantic from the sixth century в.C.E. onwards. This separation is rather artificial; there is no significant difference between the
Greek Phoinix and the Latin Poenus, insofar as both words signify outsiders' perceptions (i.e., those of the Romans and Greeks) of these groups (Prag 2014).

\section{The Materials: Figurines, Masks, and Ostrich Eggshells}

Studies on Phoenician-Punic coroplastics are many and varied (see Bisi 1990; Cherif 1997; San Nicolás 1987). Here we shall concentrate on four categories: bottle-shaped figurines, musician figurines, and both clay and eggshell masks. The bottleshaped figurines are all wheel-made. In the vast majority of cases, the figurines lack precise contextual information because they were recovered in old excavations without stratigraphic data. However, they were found in settings that housed ritual activities: these include votive deposits, cemeteries, and tophets (sacred places, located inside cities, dedicated to the deities Baal Hammon and Tannit). The figurines date from the mid-seventh century to the second century B.C.E. and have been identified mostly as representations of people praying to divinities in order to obtain offspring. The position in which they are praying is the standard one in the Eastern Mediterranean, either with the palms of the hands open, or with both hands together in front of the chest. The oil-lamps held on their heads or in their hands also 
represent prayer (fig. 2) (Ferron and Aubet 1974: 146-47). (For a stylistic, chronological, and interpretative study of these figurines, see Ferron and Aubet 1974).

The musician figurines are mold-made and date between the fifth and the third centuries B.C.E. Most of them are imports from Greece, Sicily, and Magna Graecia, although some local products have been recorded. The terracottas are mainly female and play hand-drums, doublepipes, or kitharas. They were deposited mostly in funerary chambers and shrines, and represent either goddesses or elite women (López-Bertran and Garcia-Ventura 2012) (see fig. 3).

Anthropomorphic clay masks first appeared in the Late Bronze Age in the Phoenician Levant and continued in use throughout the Iron Age. From the seventh century B.C.E. onwards, they appear in the Central (Carthage, Sicily, and Sardinia) and Western Mediterranean (the Southern Iberian Peninsula and Ibiza in the Balearic Islands). To date they have mostly been recovered in cemeteries, but they also appear in shrines, houses, and workshops. Punic masks stand out, above all, because of their expressive facial features. Exaggerated mouths, grotesque expressions, and "excessive" grinning have been used to define these materials since the midtwentieth century, when Cintas (1946) established an initial classification for the masks of the Western Mediterranean and described them all as grimacing masks (fig. 4). Other classifications exist: Picard (1965-1966) described them as demonic

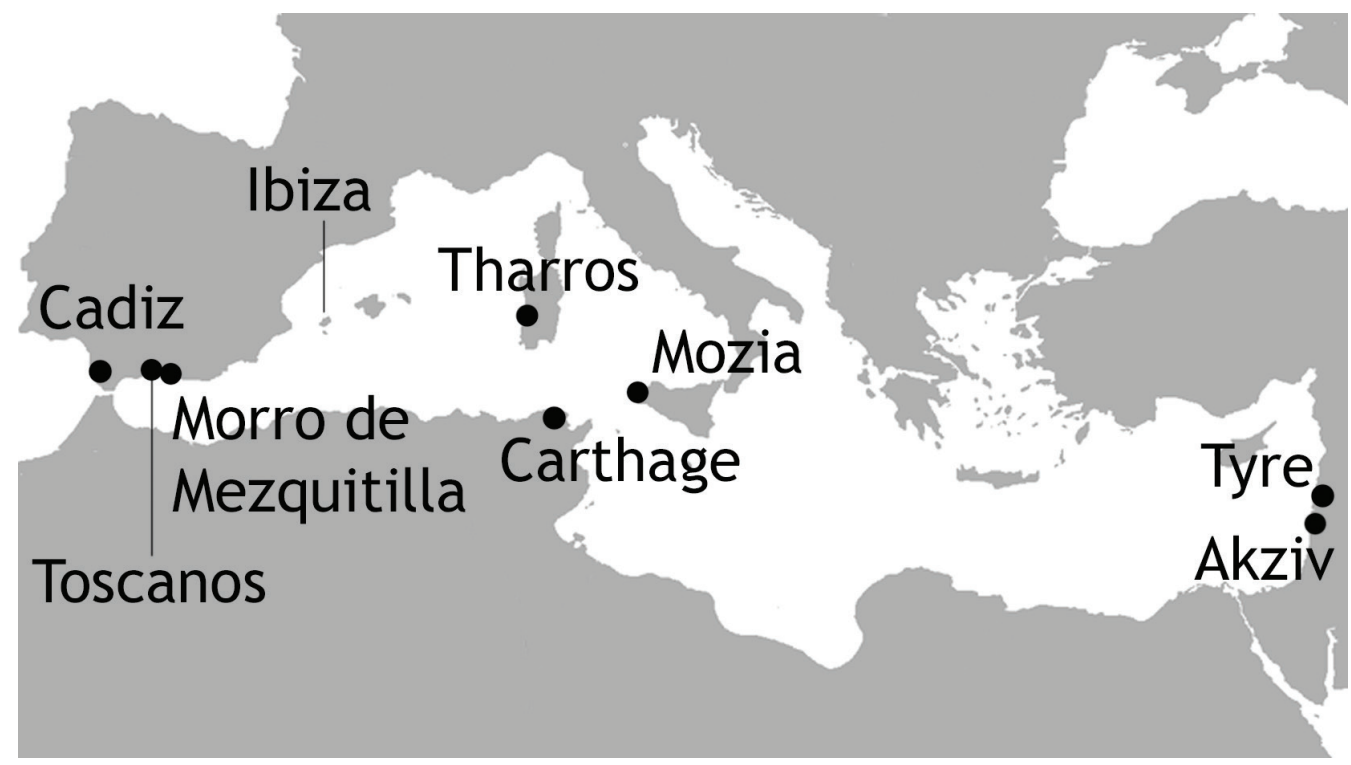

Figure 1 (above). Map of the Mediterranean showing the main Phoenician and Punic sites Modifications by Jaime Vives-Ferrándiz.

Figure 2 (below). Bottle-shaped figurines. Illa Plana shrine (Ibiza). Photographs courtesy of MAEF.

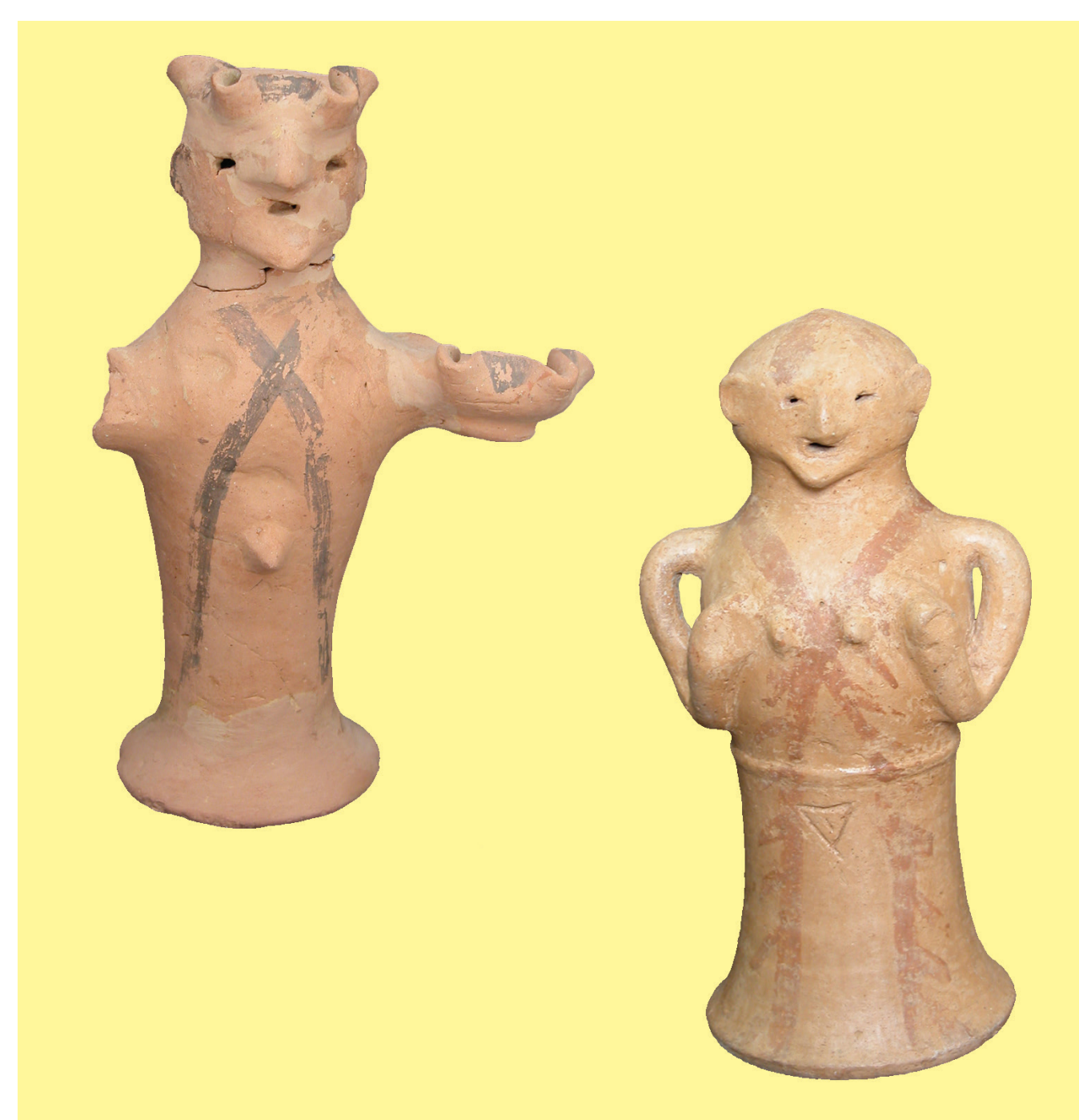



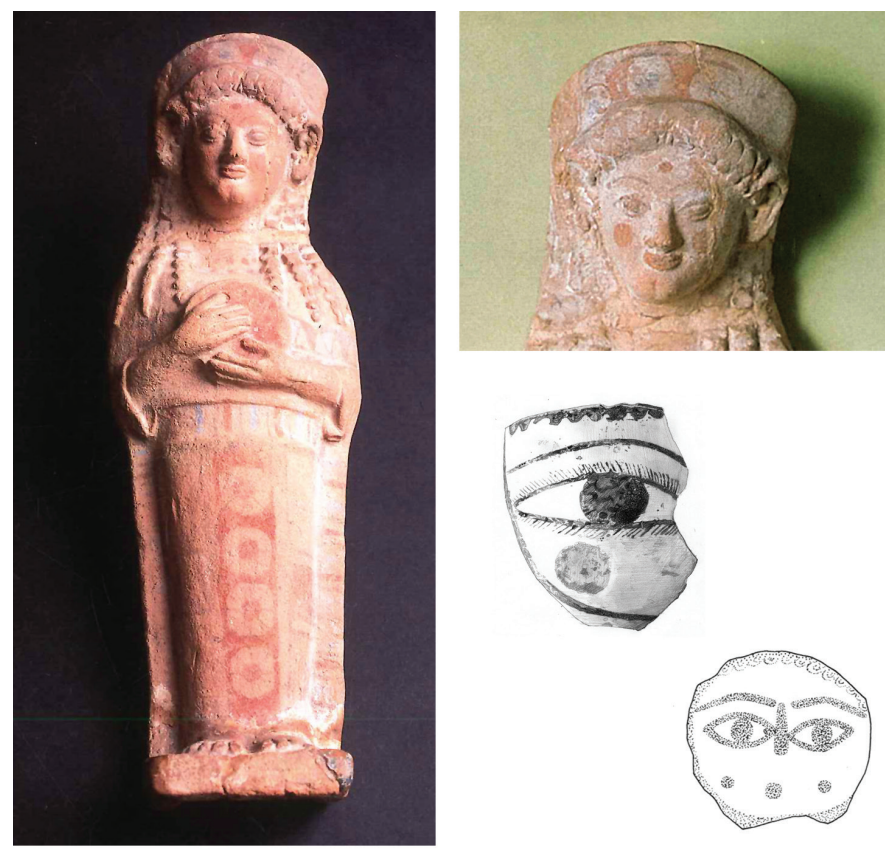

Figure 3 (above). Ostrich eggshells painted with faces from Carthage. Left: without scale in the original (drawing by Paul C. Butler). Right: $5 \mathrm{~cm}$ wide (adapted from Pisano 2004). Mold-made figurine from Carthage (images adapted from de Pedro 2004: 199 and Ben Younès 1997: 48).

Figure 4 (below). Grimacing mask from Mozia tophet, Sicily (from Moscati 1988: 360 ). With the kind permission of the Museo G. Whitaker-Isola di Mozia and the Soprintendenza per i Beni Culturali e Ambientali di Trapani (Sicilia) Inv. MO 2387.

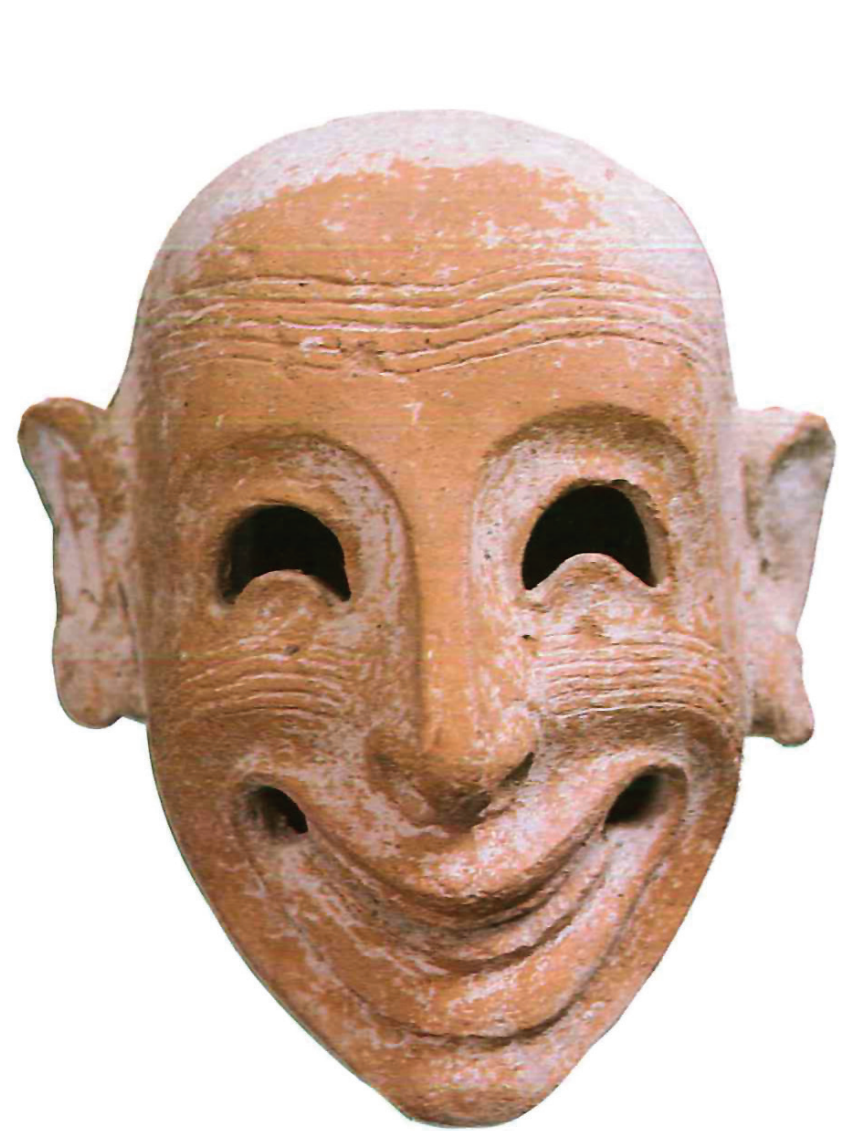



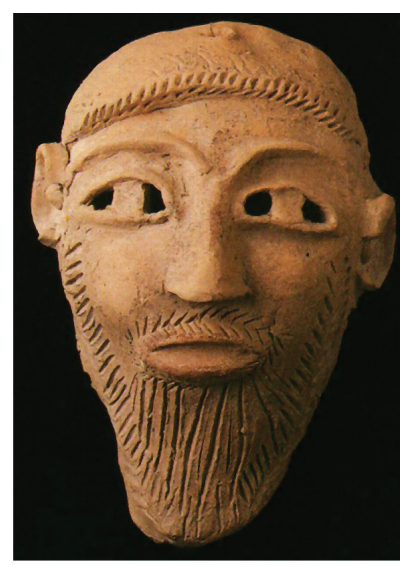

Figure 5 (above). Left: Bearded mask from Akziv cemetery (from Moscati 1988: 355). Right: Bearded mask from Ibiza (from Moscati 1988: 366).

Figure 6 (below). Cintas classification of masks (after Cintas 1946 and Moscati 1988).
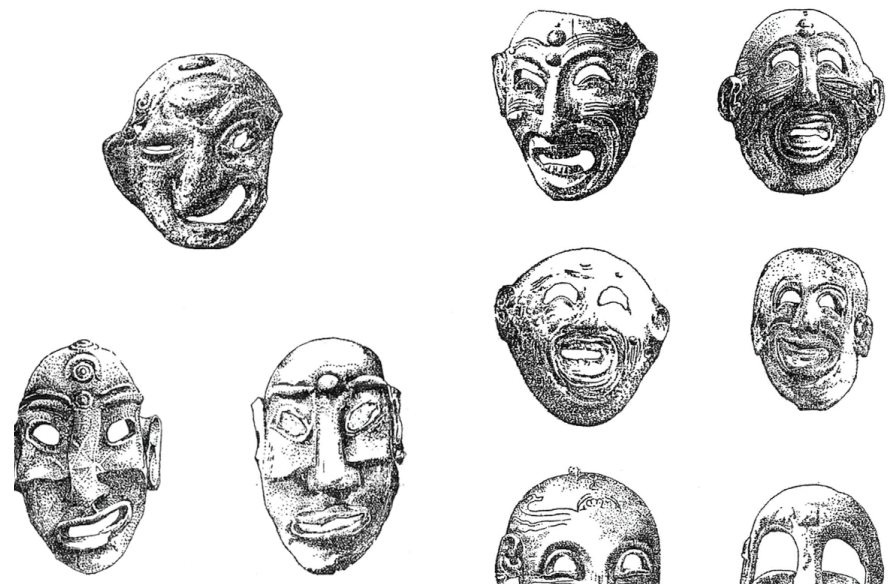

\section{Cintas I}
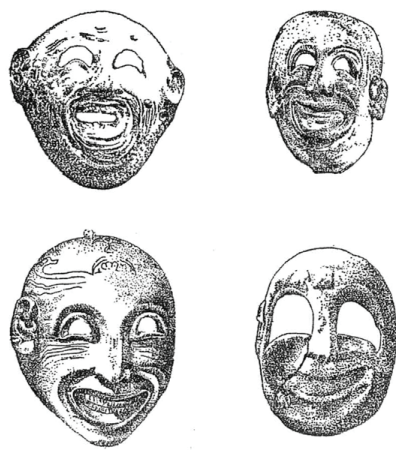

\section{Cintas II}
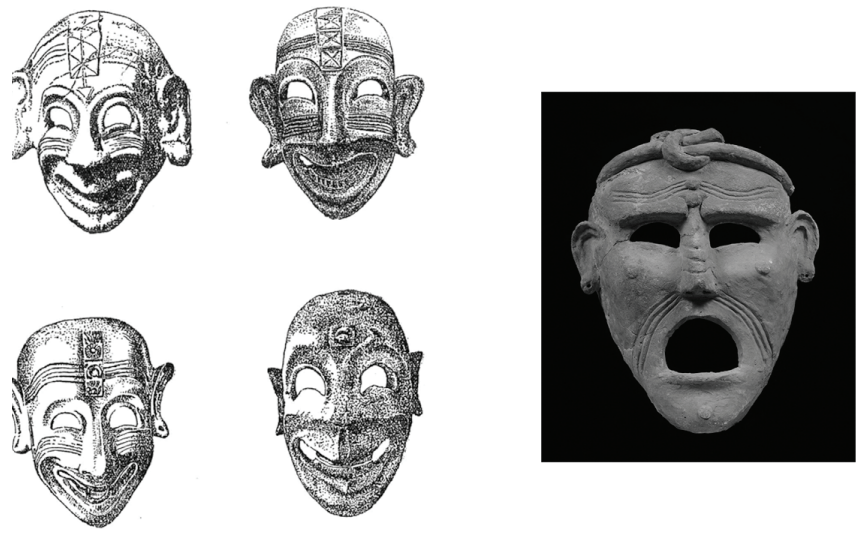

Cintas III 


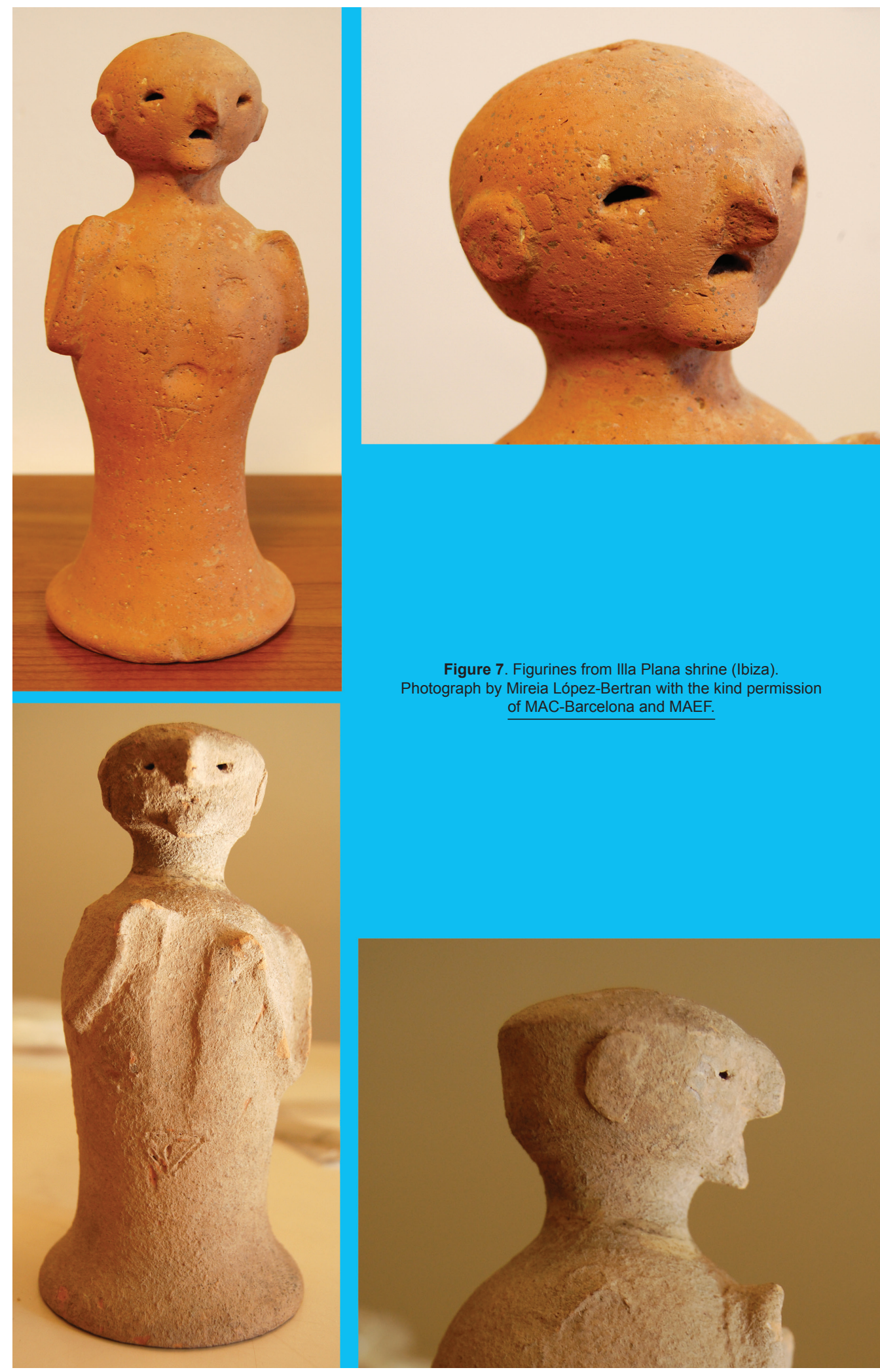

the mid-seventh century B.C.E. to the end of the third century and the beginning of the second B.C.E.

Finally, although not masks per se, a number of artifacts made of ostrich eggshell have been labelled as such, in spite of their flat shape and lack of holes, in order to distinguish them from other ostrich eggshell objects, such as bowls or cups (Astruc 1956; Pisano 2004) (fig. 3). These objects are mostly found in cemeteries but also in domestic contexts between the seventh and the second centuries B.C.E. across the Western Mediterranean. The bowls have floral and geometric decoration painted in red, while the 'masks,' which are mostly fragmentary, depict faces in black and red. Those from tombs have been linked to the role of eggs as symbols of life (Moscati 1988: 456).

\section{Engendering through Facial Characteristics (I): Beards and Pointed Chins}

Beards and facial hair have been variously interpreted as markers of sexual maturity, old age, rulership, status, and nomadism. Although the presence of a beard was not a sine qua non for the portrayal of even elite masculinity (e.g. Gudea of Lagash), such facial hair was typically used to highlight the positive attributes of male rulers and to build normative ideals about masculinity and status (e.g. Sargon of Akkad) (see Suter 2012: 442-45). As such, despite the complexity of their

masks, and, recently, Orsingher (2014) published a chronotypological sequence on the basis of the few pieces that have a clear context. In all, the masks' chronology runs from around meaning and use, beards are generally linked to males and to masculinity, as also appears true for some of the materials here under analysis. This is certainly the case for those clay 
masks that have long beards, similar to the ancient Egyptian style, or are painted black (fig. 5).

Like beards, exaggerated chins have also been considered as specifically male facial characteristics. This, however, is not always as straightforward as it appears, as is shown by some bottle-shaped figurines with exaggerated chins and incised vulvas and/or breasts (fig. 7). In this case, we might question the assumption that certain attributes, like exaggerated chins (considered as male secondary sex attributes) or breasts (considered as female secondary sex attributes), are to be understood as representing only one sex. This is clearly seen, also, in some bottle-shaped figurines with breasts and a penis (fig. 8). Furthermore, we might ask if attributes clearly linked to one sex, like beards and facial hair for males, might be used to embody status or specialization as well as or instead of gender. For example, Hatshepsut, the well-known female ruler of the Eighteenth Dynasty in Egypt (mid-second millennium B.C.E.), was often represented with a beard. ${ }^{2}$ Whether Hatshepsut was considered a king or a queen is a matter of contro-

versy, and depends mainly on how the beard is interpreted: was it a symbol of masculinity or a symbol of royalty, as has been suggested by Watterson (1998: 140)? Following Watterson's proposal and considering that some features might have had more than one meaning, in the case of the bottle-shaped figurines we suggest that exaggerated chins were linked to ritual mastery and not necessarily to masculinity (see López-Bertran 2011: 51-54), which may explain their presence on figurines with incised vulvas.

\section{Engendering through Facial Characteristics (II): Discs}

The so-called discs are facial traits that appear on diverse surfaces and in various forms. On terracotta objects they may be clay buttons added onto the core (fig. 9), although in some cases, as with the musician figurines, they are painted red circles (fig. 3). On the eggshell 'masks' they are exclusively painted red dots.

How these dots are interpreted, and their role in engenderment, depends on preconceived notions of the gender of the category of object they decorate. For example, because some terracotta masks are bearded (see above), Cintas assumed they were all male, despite the absence of beards in the vast majority of cases. He even went one step further and aged them in his typology: Cintas I masks include grinning, beardless, young people with big noses; Cintas II are grinning elderly people with tattoos; Cintas III have the same features as Cintas II, but are more exaggerated and in some cases have detailed representations of teeth; and finally Cintas IV are grotesque masks, anticipating Greek types (fig. 6). As such, when found on the terracotta masks, the discs have been interpreted either as warts (Cintas 1946: 37) or as astral symbols, especially, in the latter case, when surmounted by a crescent that turns the disc into the sun, the moon, or even Venus (fig. 11). Other decoration applied, engraved, or stamped onto the forehead, cheeks, and chin includes triangles, cruciforms, and rosettes (fig. 10) (Culican 1975-76: 67; Orsingher 2014: 154).

The ostrich eggshell 'masks', due to their funerary contexts, have been defined as faces or heads of Hathor, the Egyptian goddess of fertility and protection (Pisano 2004: $50)$. It is generally agreed that these objects thus represent females. Likewise, the musician figurines appear to be female, as indicated by their attire, breasts, and hairstyle. These objects are frequently decorated with red dots on their faces, and it is especially worth mentioning figure 25 of Chérif's catalogue (1997). This face is decorated with four red circles: one on each cheek, one on the forehead, and one on the chin, 
bearing a clear resemblance to the red circles on some of the masks and ostrich eggshells noted above (fig. 3). On these categories of objects, the facial disks are identified as feminine makeup.

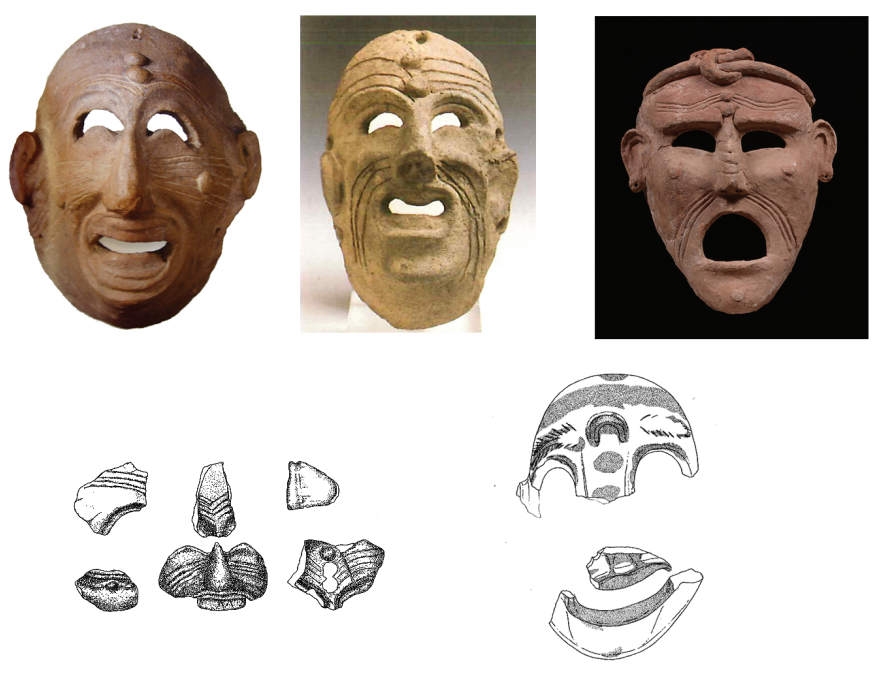

Figure 9. Masks with discs from Carthage (adapted from Moscati 1988: 358, 361 , Acquaro 1990: 55, and Niemayer and Docter 1998: 93).1988).

At this point, we want to highlight what we consider to be an engendering vicious cycle. Unlike the musician figurines or, to a certain extent, the bearded masks, neither the unbearded clay masks nor the painted ostrich eggshells have features other than facial traits and facial decoration to engender them. However, the facial discs have been interpreted in very different ways on both, always based on preconceived notions of the gender of the object in question. The fact that some masks are bearded appears to have led to the assumption that the beardless examples are also male. Consequently, when present on masks, discs are interpreted as warts or as astral symbols. However, faces depicted on ostrich eggshells which present the same features as the terracotta masks are labelled as female, with the facial discs
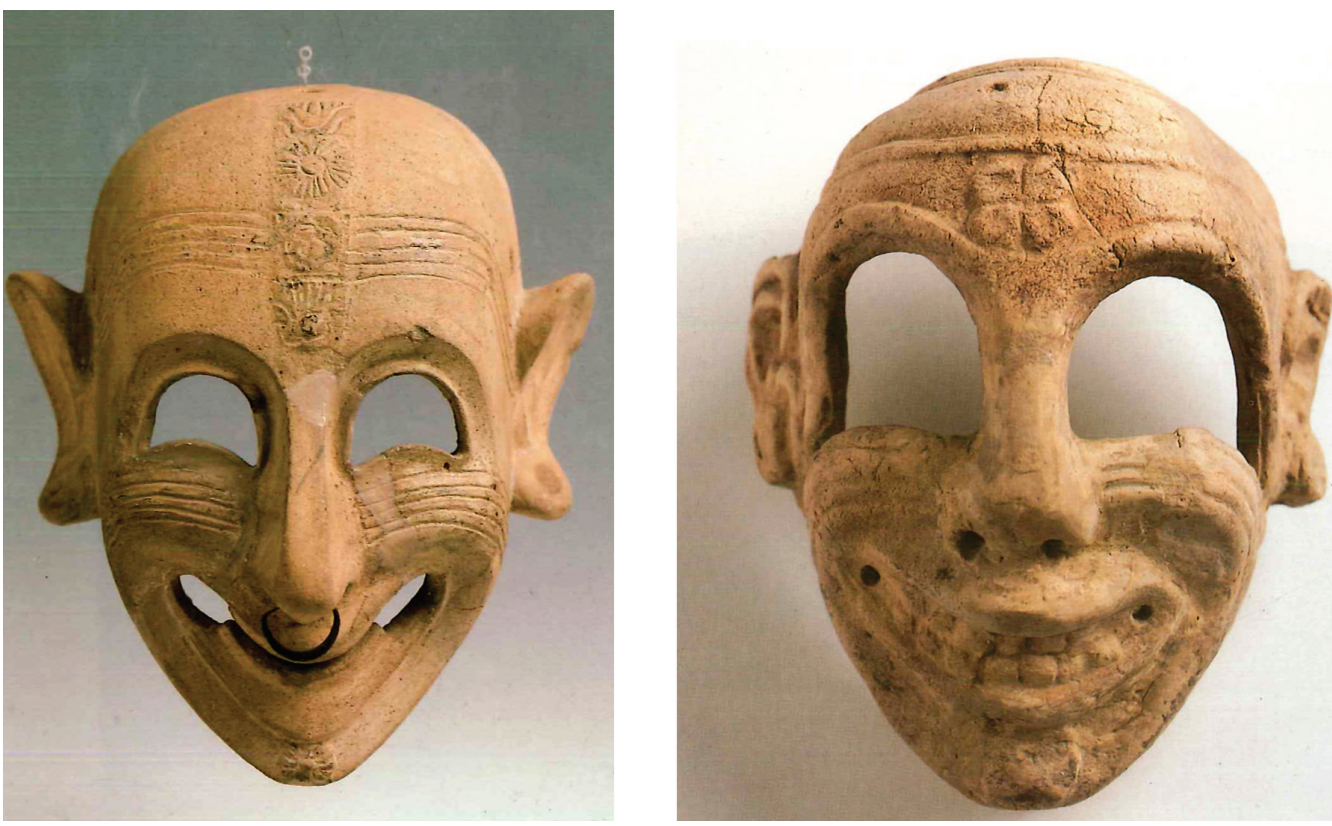

Figure 10. Masks with decorations. Left: Sardinia. Right: Ibiza (from Moscati 1988: 360, 361). another based originally upon our interpretations of the objects upon which they appeared.

Both the gender assignment of these materials and the diverse interpretations of discs expose preconceptions. The strategies used to engender such objects clearly need to be reassessed. We suggest opening up the possibility that discs might not have been exclusively linked to one gender. This facial decoration, probably painted but also tattooed or scarified, would certainly have been meaningful. The fact that they were painted red (in cases where color is preserved) is not irrelevant, as this color was imbued with magical and symbolic value for Phoenician-Punic people; discs in red probably signified poonly certain people, regardless of their gender, were allowed to display such decoration. We suggest that facial painting or tattooing might have taken place during rites of passage, rituals relating to changes in status or age. In the case of masks deposited in tombs, for example, they may have been associated with rituals enacted to ensure the deceased's journey to the next world.

\section{Reassessing Engendering Strategies in Phoenician-Punic Studies}

Our aim has been to show how careful we must be when using facial characteristics (such as discs or exaggerated chins/ beards), as well as secondary sexual characteristics (e.g. breasts), to engender anthropomorphizing artifacts. This applies especially when genitalia (primary sexual characteristics) tency and power (Culican 1976-77: 68). It is likely, then, that in this case identified as

feminine makeup. Such 'masculine' and 'feminine' attributes are then used to solidify the gender identity of the objects in question, forgetting that we defined the discs one way or are not represented, or when they are represented but with contrasting secondary characteristics, such as the figurines which have both breasts and penises, or pointed chins and vulvas. The 
images discussed above offer a considerable challenge (cf. Hamilton 2000: 25) and suggest that the interpretation of breasts and discs (when identified as makeup) as exclusively feminine and pointed chins or beards as exclusively masculine attributes is a product of our own preconceptions about what a feminine or masculine body should be (cf. Bolger 2009). We argue here that discs on masks and ostrich eggshells may have been linked to status and/or age, while figurines with pointed chins may depict ritual specialists, and thus, that these characteristics served as markers of status, age, and occupation, rather than primarily or exclusively of gender.?

\section{Notes}

1. We wish to thank Paul C. Butler for kindly providing us with a drawing of the left ostrich eggshell on figure 3 and the editors of this special issue for their help with language and comments while preparing this text. We would also like to thank Jaime Vives-Ferrándiz Sánchez for his help with the format of the images.

2. For a presumed bearded Assyrian queen sculpted on a relief of the Ishtar temple at ninth-century B.C.E. Nineveh, see McCaffrey 2002: $382-83$.

\section{References}

Acquaro, Enrico. 1990. Una maschera púnica trovata soto il cardine IX romano. Mitteilungen des Deutschen Archäologischen Instituts, Römische Abteilung 97: 54-56.

Astruc, Miriam. 1956. Traditions funéraires de Carthage. Cahiers de Byrsa 6: 29-58.

Aubet, María Eugenia. 2001. Phoenicians and the West: Politics, Colonies and Trade. Cambridge: Cambridge University Press.

Ben Younès and Alia Krandel, eds. 1997. La femme tunisienne à travers les âges. Tunis: Institut National de Patrimoine.

Bisi, Ana Maria. 1990. Le terrecotte figurate fenicie e puniche in Italia.

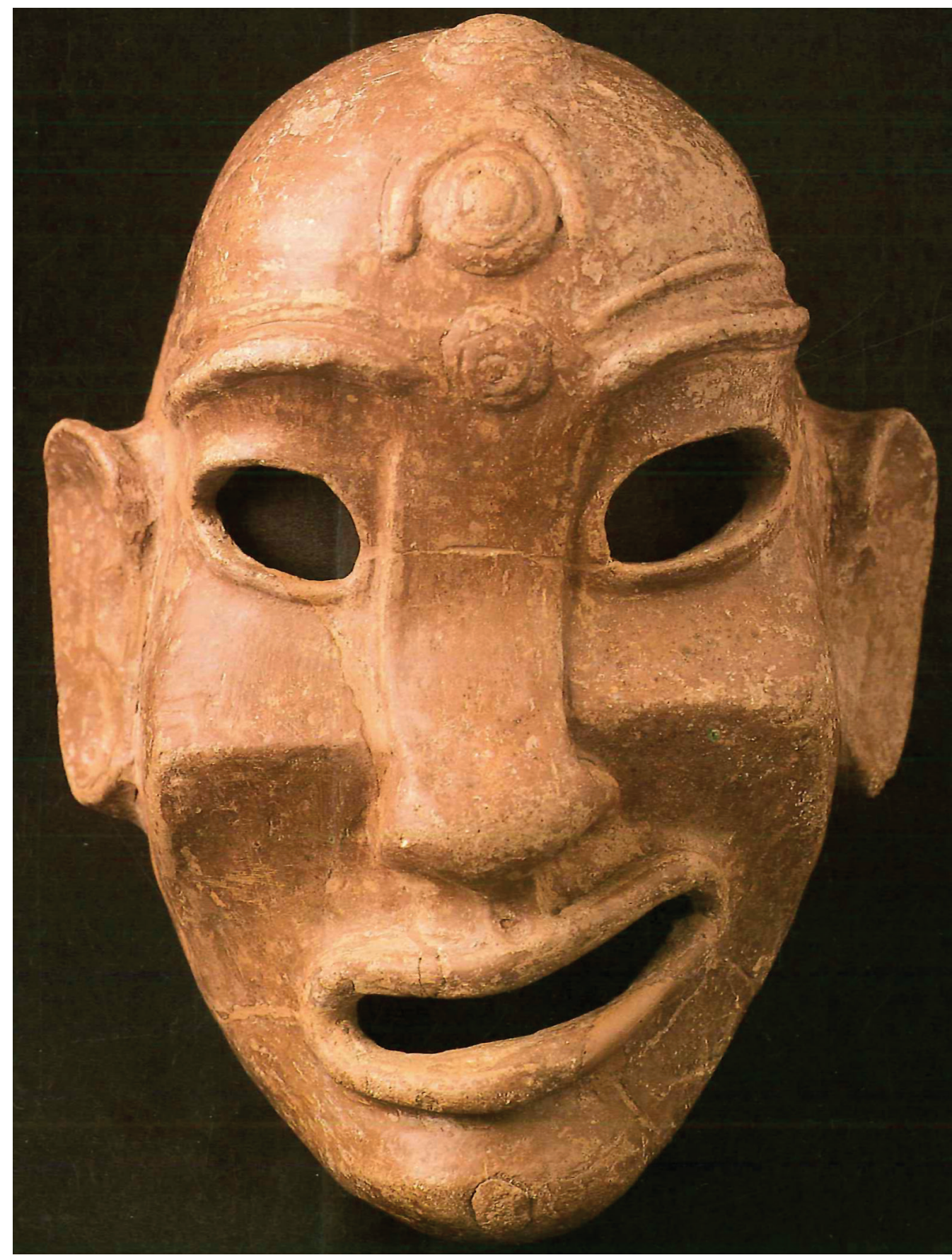

Figure 11. Mask from Carthage (from Moscati 1988: 359).

Roma: Istituto poligrafico e Zecca dello stato.

Bolger, Diane. 2009. Beyond Male/Female: Recent Approaches to Gender in Cypriot Prehistory. Pp. 41-48 in Fylo. Engendering Prehistoric "Stratigraphies" in the Aegean and the Mediterranean. Proceedings of an International Conference, University of Crete, Rethymno 2-5 June 2005, ed. Katherina Kopaka. Aegaeum 30. Liège: Université de Liège, University of Texas at Austin.

Cherif, Zohra. 1997. Terres cuites puniques de Tunisie. Corpus delle Antichità fenicie e puniche. Rome: Bonsignori Editori. 
Cintas, Pierre. 1946. Amulettes puniques. Tunis: Institut des Hautes Études.

Ferron, Jean and María Eugenia Aubet. 1974. Orants de Carthage. Collection Cahiers de Byrsa, Série Monographies 1. Paris: Paul Geuthner.

Hamilton, Naomi. 2000. Ungendering Archaeology: Concepts of Sex and Gender in Figurine Studies in Prehistory. Pp. 17-30 in Representations of Gender from Prehistory to the Present, eds. Moira Donald and Linda Hurcombe. London, New York: McMillan Press, St. Martin's Press.

López-Bertran, Mireia. 2011. Where Are the Priests? Ritual Mastery in Punic Shrines. Pp. 43-60 in Ritual Dynamics in the Ancient Mediterranean. Agency, Emotion, Gender, Representation, ed. Angelos Chaniotis. Heidelberger Althistorische Beiträge und Epigraphische Studien 49. Stuttgart: Franz Steiner Verlag.

López-Bertran, Mireia and Agnès Garcia-Ventura. 2012. Music, Gender and Rituals in Ancient Mediterranean: Revisiting the Punic Evidence. World Archaeology 44.3: 393-408.

McCaffrey, Kathleen. 2002. Reconsidering Gender Ambiguity in Mesopotamia: Is a Beard just a Beard? Pp. 379-91 in Sex and Gender in the Ancient Near East. Proceedings of the 47th Rencontre Assyriologique Internationale, Helsinki, July 2-6, 2001, eds. Simo Parpola and Robert M. Whiting. Helsinki: The Neo-Assyrian Text Corpus Project.

Moscati, Sabatino, ed. 1988. I fenici. Milan: Bompiano.

Niemayer, Hans Georg and Roald F. Docter. 1998. Excavación bajo el Decumano maximo de Cartago durante los años
1986-1995: informe preliminar. Pp. 47-110 in Cartago fenicio-púnica. Las excavaciones alemanas en Cartago 1975-1997, ed. Mercedes Vegas. Barcelona: Publicaciones del Laboratorio de Arqueología de la Universidad Pompeu Fabra.

Orsingher, Adriano. 2014. Listen and Protect: Reconsidering the Grinning Masks after a Recent Find from Motya. Vicino Oriente 43: 145-71.

Picard, Colette Gilbert. 1965-1966. Sacra Punica. Étude sur les masques et rasoirs de Carthage. Karthago 13: 1-115.

de Pedro, María Jesús, ed. 2004. Tunísia, Terra de Cultures. València: Bancaixa.

Pisano, Giovanna. 2004. Beni di lusso nel mondo punico. Le uova di struzzo III-Volti o maschere? Saguntum 36: 47-52.

Prag, Jonathan R.W. 2014. Phoinix and Poenus: Usage in Antiquity. Pp. 11-23 in The Punic Mediterranean. Identities and the Identification from Phoenician Settlement to Roman Rule, eds. Josephine Crawley Quinn and Nicholas Clive Vella. British School at Rome Studies. Cambridge: Cambridge University Press.

San Nicolás, María Pilar. 1987. Las terracotas figuradas de la Ibiza Púnica. Rome: Consiglio Nazionale delle Ricerche.

Suter, Claudia E. 2012. The Royal Body and Masculinity in Early Mesopotamia. Pp. 433-58 in Menschenbilder und Körperkonzepte im Alten Israel, in Ägypten und im Alten Orient, eds. Angela Berjelung, Jan Dietrich, and Joachim Friedrich Quack (eds.): Tübingen: Mohr Siebeck.

Watterson, Barbara. 1998. Women in Ancient Egypt. Stroud: Sutton Publishing.



